\title{
PELATIHAN PENINGKATAN KOMPETENSI GURU DALAM MENGIDENTIFIKASI PERILAKU BERESIKO PADA ANAK DI SMP MUHAMMADIYAH 1 JEMBER
}

\author{
Siti Nur'aini ${ }^{1)}$, Ria Wiyatfi Linsiya ${ }^{2)}$ \\ sitinuraini@unmuhjember.ac.id ${ }^{1)}$,ria.wiyatfi@unmuhjember.ac.id ${ }^{2)}$ \\ Fakultas Psikologi Universitas Muhammadiyah Jember ${ }^{1), 2)}$
}

\begin{abstract}
ABSTRAK
Pada dasarnya remaja memiliki resiko untuk melakukan tindakan yang mengarah pada perilaku kenakalan remaja. Perilaku ini juga seringkali ditunjukkan oleh remaja di lingkungan sekolah. Guru juga memiliki peran untuk dapat membantu mengatasi permasalahan kenakalan remaja.Oleh sebab itu, guru diharapkan memiliki kemampuan untuk dapat mengidentifikasi perilaku remaja di sekolah (siswa).Tujuan pelatihan untuk guru tersebut ialah guru memiliki keterampilan identifikasi perilaku siswa yang cenderung agresif dan tidak disiplin kepada seluruh guru yang berada di SMP Muhammadiyah I Jember.

MetodePelaksanaan dalam pelatihan ini dirancang dengan beberapa kegiatan agar kegiatan ini berjalan dengan optimal diantaranya : Asesmen awal, penyusunan proposal penelitian, pelaksanaan pelatihan, pendampingan guru serta evaluasi. Hasil evaluasi pada pelaksanaan pelatihan tersebut menunjukkan bahwa secara keseluruhan peserta pelatihan menilai baik pelaksanaan pelatihan yang telah dilakukan namun ada beberapa aspek yang perlu di perhatikan oleh pemateri yaitu pada aspek durasi waktu pelaksanaan dirasa masih cukup oleh $28,6 \%$ peserta dan $14.3 \%$ peserta merasa kurang lama pelaksanaannya, hal ini di sebabkan factor perijinan waktu yang di sediakan oleh pihak sekolah. Sedangkan pada aspek media penunjang yang di gunakan oleh pemateri masih ada $14.3 \%$ peserta merasa cukup
\end{abstract}

Kata kunci; pelatihan, identifikasi, perilaku beresiko, kenakalan remaja

\section{PENDAHULUAN}

Remaja identik dikatakan sebagai masa peralihan dalam proses untuk mencari jati diri. Perkembangan remaja banyak dipengaruhi oleh lingkungan sosialnya diantaranya orang tua, guru, keluarga, dan orang-orang di sekitarnya. Pada tahap ini individu akan mencari identitas diri untuk mengembangkan keribadiannya. Keadaan ini yang menimbulkan situasi konflik yang 
mengakibatkan masalah yang berkaitan dengan kesehatan remaja baik fisik maupun psikososial (Herero, 2006). Situasi konflik tersebut biasanya termanifestasi dalam kenakalan remaja yang seringkali dilakukan di lingkungan baik di rumah, sekolah maupun tempat-tempat umum.

Menurut Taftazani (2013) bahwa kenakalan remaja menjadi permasalahan sosial yang seringkali terjadi di Indonesia. Perilaku tersebut juga sebagai masalah yang cukup mengkhawatirkan. Dampak yang ditimbulkannya, bentukbentuk perilaku remaja tidak lagi sebagai kenakalan biasa karena terkadang melibatkan bentuk perilaku yang berkaitan dengan hukum dan tidak jarang menyebabkan adanya korban yang terluka hingga meninggal dunia. Salah satu bentuk kenakalan remaja ialah agresivitas.

faktor-faktor risiko yang diidentifikasi menjadi potensi pada remaja dalam mengembangan perilaku agresif diantaranya harga diri rendah (Martínez, Murgui,Musitu, \& Monreal, 2009), kepuasan hidup rendah (Alcántara et al., 2016), perasaan kesepian (Martínez, Povedano, Amador,\& Moreno, 2012), tekananpsikologis (Villarreal-González, Sánchez-Sosa, Veiga, \& del Moral Arroyo, 2011),Berdasarkan hasil penelitian yang menunjukkan bahwaperilaku agresif ditunjukkan oleh beberapa remaja di lingkungansekolah mengacu pada serangkaian perilaku yang ditujukan pada teman sekelas lain maupun guru hingga menyebabkan dampak pada fisik, psikologis, verbal, maupun relasional (Estévez, Moreno, Jiménez, \& Musitu, 2013; Little, Henrich, Jones, \& Hawley,2003). Beberapa studi menunjukkan perilaku agresif ini telah dianggap sebagai prediktor kenakalan remaja dimana yang melakukan perilaku tersebut akan menyebabkan risiko tinggi pada hambatan/kesulitan emosional, psikologis, dan permasalahan di sekolah dalam jangka pendek maupun jangka panjang (Vanderbilt \& Augustyn, 2010).

SMP muhammadiyah 1 Jember merupakan salah satu sekolah Islam yang berada di miliki oleh Persyarikatan Muhammadiyah. SMP Muhammadiyah 1 Jember memiliki tujuan untuk membentuk karakter siswa yang berakhlak mulia serta unggul dalam prestasi akademik dan non akademik. Upaya yang dilakukan oleh sekolah untuk dapat mencapai tujuannya selain melakukan pendampingan 
secara intens di bidang akademik, juga di lakukan pendampingan non akademik melalui kegiatan-kegiatan ekstrakulikuler dan kegiatan pembinaan keagamaan. Pendampingan yang dilakukan juga sebagai upaya preventif dalam mengatasi perilaku siswa saat ini yang semakin beragam dan kompleks, bahkan beberapa kasus yang di tangani guru BK sudah mulai muncul perilaku-perilaku siswa yang cenderung mengarah pada perilaku agresif.

Hasil observasi dan wawancara dengan Guru Bimbingan Konseling di SMP Muhammadiyah Jember menyatakan bahwa banyak siswa yang sering melakukan tindakan kenakalan remaja salah satunya perilaku agresivitas. Beberapa siswa sering kali melakukan tindakan agresivitas seperti mengumpat pada teman dan guru, melukai teman, berkelahi dengan teman, melawan dan membentak terhadap guru, merusak fasilitas di sekolah dan lain sebagainya. Selain itu, banyak siswa yang enggan dan tidak patuh terhadap peraturan disekolah dengan berbagai konsekuensi yang telah ditetapkan dan menjadi kebijakan sekolah.

Sikap guru dalam mengatasi perilaku siswa juga beum tepat, karena sering kali guru telah merasa seringkali memberikan peringatan, namun di abaikan oleh siswa, Dengan adanya sikap guru yang Begitu juga guru yang kurang adekuat dalam memberikan teguran dan menerapkan hukuman yang tegas terhadap siswa, maka siswa cenderung melakukan pelanggaran berulang.

Hasil dari wawancara dengan beberapa siswa mengungkapkan bahawa terkadang, masih ada beberapa guru menampakkan perilaku yang cenderung kurang sabar ketika menghadapi teman-temannya yang bermasalah, dengan memunculkan kata-kata ksar, menunjukkan sikap tidak senang atau memarahi ketika berhadapan dengan siswa-siswa yang dianggap bermasalah, hal ini semakin memperkuat perilaku siswa untuk memunculkan perilaku yang cenderung agresif. Hal ini juga di perkuat oleh latar belakang orang tua siswa yang berbeda-beda serta lingkungan dimana siswa bertempat tinggal.

Peran orang tua dan guru memiliki peran penting dalam membentuk perilaku anak, karena anak masih membutuhkan dukungan dan control dalam memunculkan perilaku. Berdasarkan penjelasan tersebut maka orang tua dan 
guru di sekolah seharusnya memiliki peranan penting untuk dapat meminimalisir atau mengatasi permasalahan agresif yang dialami oleh siswa. Salah satu bentuk peranan orang tua ialah dengan menerapkan pola asuh sebagai bentuk sikap orang tua dalam mendidik anak ketika berada di dalam keluarga. Menurut Kohn, pola asuh sendiri merupakan sikap orang tua dalam berinteraksi dengan anakanaknya (Habibi, 2015). Sikap orang tua tersebut diantaranya dalam pemberian aturan-aturan, hadiah, hukuman, adanya otoritas sebagai orang tua, serta memberikan tanggapan dan perhatian terhadap anak. Dalam membantu pembentukan sikap dan perilaku positif siswa, guru pembimbing dapat memberikan layanan informasi mengenai penyebab munculnya agresi dan sangsi yang diperoleh apabila melakukan tindakan agresi (Hidayat,Yusri \& Ilyas, 2013). Tidak hanya itu, tetapi juga harus menerapkan teguran dan sangsi secara tegas tanpa membedakan siswa. Layanan ini dapat di berikan secara kelompok danindividual.

Layanan Konseling Perorangan adalah layanan yang memungkinkan peserta didik mendapatkan layanan langsung tatap muka secara perorangan dengan guru pembimbing dalam rangka pembasan dan pengentasan masalah pribadi yang dialami siswa. Melalui layanan ini guru pembimbing dapat membantu siswa yang mengalami masalah dalam kehidupan sehari-hari menyangkut tindakan agresi seperi masalah siswa yang berkelahi, berkata-kata kotor dan merusak fasilitas sekolah (Hidayat, Yusri \& Ilyas, 2013). Namun disisi lain, tidak hanya guru pembimbing namun diharapkan pada semua guru yang berada di sekolah memiliki keterampilan identifikasi pada perilaku siswa yang cenderung agresif dan tidak disiplin. agar dapat merubah perilaku siswa dengan optimal terutama di lingkup sekolah.

Berdasarkan data di lapangan menunjukkan bahwa siswa yang cenderung agresif dan tidak disiplin selalu menjadi tugas dan tanggung jawab guru bimbingan konseling dalam menyelesaikan permasalahan sehingga banyak kasus di sekolah yang tidak dapat terselesaikan. Berdasarkan fenomena ini, maka dibutuhkan peran seluruh guru yang ada di sekolah untuk dapat mengidentifikasi perilaku siswa yang cenderung agresif dan tidak disiplin. Oleh sebab itu, guru 
diharapkan memiliki keterampilan dan dapat membantu dalam menangani maupun mendampingi siswa yang melakukan tindakan cenderung berperilaku agresif disekolah.

\section{SOLUSI DAN PERMASALAHAN}

Assesmen penggalian data telah dilakukan pada bulan Maretvsampai dengan bulan April 2019 dan muncul permasalahan kurangnya keterampilan guru dalam mengidentifikasi perilaku siswa yang cenderung agresif dan tidak disiplin. Hal ini yang semakin memicu banyaknya siswa yang melakukan tindakan agresif dan melanggar aturan yang ditemukan pada siswa di SMP Muhammadiyah I Jember. Solusi yang bisa diberikan untuk mengatasi permasalahan tersebut adalah dengan mengadakan pelatihan untuk guru yang berupa keterampilan identifikasi perilaku siswa yang cenderung agresif dan tidak disiplin kepada seluruh guru yang berada di SMP Muhammadiyah I Jember. Hal ini diharapkan dapat meningkatkan kualitas pelayanan guru terhadap siswa dan dapat membantu dalam menangani maupun mendampingi siswa yang melakukan tindakan agresif di sekolah.

\section{METODE PELAKSANAAN}

Kegiatan pengabdian masyarakat dirancang dengan beberapa kegiatan, yang bertujuan supaya pelaksanaan kegiatan ini berjalan dengan optimal. Adapun metode pelaksanaan yang di rencanakan sebagai berikut :

Tabel 1 Pelaksanaan Kegiatan

\begin{tabular}{|l|l|l|l|}
\hline No & Pelaksanaan kegiatan & \multicolumn{1}{|c|}{ Tahapan } & \multicolumn{1}{|c|}{ Keterangan } \\
\hline 1 & Maret - April 2019 & Assesment awal & $\begin{array}{l}\text { Tahapan ini di awali degan } \\
\text { wawancara dan observasi, pada } \\
\text { guru, guru bimbingan konseling } \\
\text { dan siswa untuk mengetahui } \\
\text { kondisi kancah } \\
\text { yang sesunguhnya }\end{array}$ \\
\hline 2 & April 2019 & Penyusunan Proposal Penelitian & $\begin{array}{l}\text { Proposal di susun setalah } \\
\text { mendapatkan data awal dari } \\
\text { assessment yang telah dilakukan }\end{array}$ \\
\hline
\end{tabular}




\begin{tabular}{|c|c|c|c|}
\hline 3 & Mei 2019 & Tahap perencanaan & $\begin{array}{l}\text { Pada tahap kedua ini, } \\
\text { hasilassesmnet awal di gunakan } \\
\text { sebagai acuan } \\
\text { mennentukan } \\
\text { dalamkegiatanpengadian } \\
\text { masyarakat, penyusunan materi, } \\
\text { pembuatan modul pelatihan dan } \\
\text { penyusunan lembar assessment } \\
\text { guru }\end{array}$ \\
\hline 4 & 24 Mei 2019 & Pelaksanaan pelatihan & $\begin{array}{l}\text { Peserta pelatihan semua guru } \\
\text { disekolah }\end{array}$ \\
\hline 5 & Juni 2019 & Pendampingan Guru & $\begin{array}{l}\text { Kegiatan bertujuan untuk } \\
\text { mendampingi melakukan praktek } \\
\text { secara langsung guru wali kelas } \\
\text { untuk mengisi form identifikasi } \\
\text { perilaku siswa dan melakukan } \\
\text { klasifikasi dan penanganan } \\
\text { permasalahan siswa pada kasus- } \\
\text { kasus ringan. }\end{array}$ \\
\hline 6 & Juni 2019 & Tahapan evaluasi & $\begin{array}{ll}\text { Evaluasi di lakukan } & \text { untuk } \\
\text { mengetahui } & \\
\text { efektivitaspelatihanyang } & \text { telah } \\
\text { dilaksanakan } & \end{array}$ \\
\hline
\end{tabular}

\section{LUARAN DAN TARGET CAPAIAN}

Tabel 2 Luaran Kegiatan

\begin{tabular}{|l|l|l|c|c|c|}
\hline \multirow{2}{*}{ No } & \multicolumn{3}{|c|}{ Jenis Luaran } & $\begin{array}{c}\text { Indikator } \\
\text { Capaian }\end{array}$ \\
\hline 1 & Kategori & \multicolumn{1}{|c|}{ Sub Kategori } & Wajib & Tambahan & \\
\cline { 2 - 6 } & Artikel Ilmiah & Nasional Terakreditas & & & Submit \\
\hline 2 & Modul & $\begin{array}{l}\text { Nasional tidak terakreditasi } \\
\text { siswa identifikasi perilaku }\end{array}$ & & $\mathrm{v}$ & $\begin{array}{c}\text { Telah tersusun } \\
\text { dan di gunakan } \\
\text { oleh guru wali } \\
\text { dan guru BK }\end{array}$ \\
\hline
\end{tabular}

\section{HASIL PENGABDIAN MASYARAKAT}

Remaja merupakan masa peralihan individu dalam proses pencarian identitas diri serta dalam rangka mengembangkan personality, pada proses ini seringkali remaja mengalami situasi konflik yang secara tidak langung akan berdampak terhadap kesehatan fisik, psikologis maupun perkembangan sosialnya, ketika remaja tidak mampu mengatasi konflik tersebut akan cenderung memunculkan perilaku yang cenderung agresif. Upaya preventif yang perlu dilakukan untuk meminimalisir munculnya perilaku agresif pada anak adalah mengoptimalkan peran lingkunga, terutama orang tua dan guru.

SMP Muhammadiyah 1 Jember, merupakan salah satu sekolah yang fokus 
membantu siswa untuk mengembangkan karakter positif, diharapkan siswa tidak hanya memiliki prestasi akademik, namun juga memiliki soft skill dan akhlak yang mulia. Namun upaya yang dilakukan tidak cukup untuk optimal untuk meminimalisir perilaku agresif siswa, karena perngaruh eksternal yang sangat kuat, untuk mengatasi tersebut sekolah berupaya melakukan upaya preventif dengan memberikan bekal kepada guru untuk memiliki ketrampilan dalam mengidentifikasi perilaku-perilaku beresiko siswa. Kegiatan ini dilakukan supaya guru lebih dini mengidentifikasi perilaku siswa, sehingga ketika ada siswa yang nampak memunculkan kecenderungan perilaku agresif segera dapat tertangani dan tidak berdampak kepada siswa-siswa yang lainnya.

Kegiatan pengabdian masyarakat dilaksanakan melalui beberapa tahapan, kegiatan ini dilaksanakan di SMP Muhammadiyah 1 Jember. Peserta kegiatan ini di fokuskan kepada guru kelas dan guru Bimbingan Konseling, hal ini dilakukan dengan pertimbangan guru kelas, memiliki tugas untuk melakukan pendampingan secara intensif dengan siswa baik dalam kegiatan akademik dan non akademik, guru kelas juga memiliki jadwal khusus bertemu dengan siswa untuk melakukan sesi dialog, kegiatan ini bertujuan untuk mengidentifikasi kesulitsan atau permasalahan yang di hadapi oleh siswa-siswa dalam proses akademik.

Kegiatan pengabdian masyarakat inidi rancang untuk melakukan beberapa kegiatan, adapun kegiatan yang di lakukan meliputi Assesment awal. Kegiatan ini dilaksanakan pada bulan Maret sampai April 2019, Tahapan ini di awali dengan wawancara dan observasi, pada guru, guru bimbingan konseling dan siswa, kegiatan ini bertujuan untuk mengetahui kondisi kancah yang sesunguhnya. Tahap selanjutnya adalah Tahap perencanaan dan persiapan. Pada tahap kedua ini, tim melakukan analisa dari hasilassesmeent awal di gunakan sebagai acuan untuk menentukan tema dalamkegiatan, sekaligus menyusun materi dan modul pelatihan.

Kegiatan Pelatihan. Kegiatan ini dilaksanakan pada hari Jum'at 24 Mei 2019, di ikuti oleh Kepala sekolah, wakil kepala sekolah bidang kesiswaan, guru wali kelas, guru BK, pada kegiatan ini guru dilatih untuk dapat memiliki 
kemampuan dan ketrampilan mengidentifikasi perilaku-perilaku beresiko pada siswa, salah satu kegiatan yang di laksanakan adalah FGD dengan guru-guru untuk mengindetifikasi perilaku-perilaku siswa yang dinilai perilaku beresiko oleh guru. Setelah dilakukan kegiatan pelatihan, di lanjutkan pada kegiatan pendampingan. Kegiatan pendampingan ini dilakukan tiga kali tujuan kegiatan ini untuk mendampingi melakukan praktek secara langsung guru wali kelas untuk mengisi form identifikasi perilaku siswa dan melakukan klasifikasi dan penanganan permasalahan siswa pada kasus-kasus ringan. Sekolah akan di buatkan buku yang berisi tentang form, sehingga memudahkan guru untuk mengidentifikasi perilaku siswa

Kegiatan pengabdian masyarakat ini di akhiri dengan pelaksanaan evaluasi kegiatan. Kegiatan evaluasi ini dilakukan untuk mengetahui efektivitas pelatihan yang telah dilakukan oleh Tim pelaksana. Adapun aspek-aspek yang di nilai meliputi kesesuaian materi, durasi waktu pelaksanaan, sistematika penyampaian materi penggunaan bahasa yang di gunakan oleh pemateri dan media penunjang yang di gunakan oleh pemateri. Selanjutnya hasil evaluasi di analisa untuk mengetahui hasil dan efektifitas kegiatan pengabdian masyarakat yang telah di lakukan. Adapun hasilnya sebagai berikut :

Tabel 3 Hasil evaluasi Pelatihan

\begin{tabular}{|c|c|c|c|c|}
\hline No & Indikator Penilaian & frequency & Prosentase & Keterangan \\
\hline \multirow[t]{2}{*}{1} & \multirow{2}{*}{$\begin{array}{l}\text { Materi / topic sesuai dengan } \\
\text { kebutuhan guru kelas \& } \\
\text { guru BK }\end{array}$} & 8 & $57.1 \%$ & Baik \\
\hline & & 6 & $42.9 \%$ & Sangat baik \\
\hline \multirow[t]{4}{*}{2} & \multirow[t]{4}{*}{ Durasi/waktu pelaksanaan } & 1 & $7.1 \%$ & Sangat baik \\
\hline & & 7 & $50 \%$ & Baik \\
\hline & & 4 & $28.6 \%$ & Cukup \\
\hline & & 2 & $14.3 \%$ & kurang \\
\hline \multirow[t]{2}{*}{3} & \multirow{2}{*}{$\begin{array}{l}\text { Sistematika penyampaian } \\
\text { materi }\end{array}$} & 4 & $28.6 \%$ & Sangat baik \\
\hline & & 10 & $71.4 \%$ & baik \\
\hline \multirow[t]{2}{*}{4} & \multirow{2}{*}{$\begin{array}{l}\text { Narasumber menggunakan } \\
\text { bahasa yang mudah di } \\
\text { pahami }\end{array}$} & 6 & $42.9 \%$ & Sangat baik \\
\hline & & 8 & $57.1 \%$ & baik \\
\hline \multirow[t]{2}{*}{5} & \multirow{2}{*}{$\begin{array}{l}\text { Media yang digunakan } \\
\text { menunjang materi }\end{array}$} & 12 & $85.7 \%$ & Baik \\
\hline & & 2 & $14.3 \%$ & Cukup \\
\hline
\end{tabular}

Berdasarkan hasil evaluasi diatas, Nampak bahwa secara keseluruhan peserta pelatihan menilai baik pelaksanaan pelatihan yang telah dilakukan, materi 
atau topic yang di sampaikan kepada guru sudah baik dan sesuai dengan kebutuhan guru, sistematika penyampaiakn juga dapat di terima dengan baik oleh para peserta begitu juga dengan penggunaan bahasa yang digunakan oleh narasumber mudah di pahami oleh peserta, namun ada beberapa aspek yang perlu di perhatikan oleh pemtaeri yaitu pada aspek durasi waktu pelaksanaan di rasa masih cukup oleh $28,6 \%$ peserta dan $14.3 \%$ peserta merasa kurang lama pelaksanaannya, hal ini di sebabkan factor perijinan waktu yang di sediakan oleh pihak sekolah. Sekolah mengijinkan kegiatan di lakukan 1 hari yang waktunya kurang lebih 5 jam, hal ini di karenakan kegiatan guru sedang padat bersamaam dengan kegiatan akhir semester. Sedangkan pada aspek media penunjang yang di gunakan oleh pemateri masih ada $14.3 \%$ peserta merasa cukup, saran dari peserta agar materi di berikan contoh video contoh penanganan indentifikasi perialku siswa, sehingga peserta jauh lebih mudah memahami cara berlatih mengidentifikasi.

\section{KESIMPULAN DAN SARAN}

Hasil dari kegiatan pengabdian masyarakat ini di nilai baik oleh para peserta, hal ini Nampak dari hasil evaluasi yang menggambarkan secara keseluruhan peserta menilai pelaksanaan pelatihan baik

Saran yang diberikan oleh peserta meliputi kurangnya durasi waktu untuk praktek langsung selama pelatihan dan di perlukan kegiatan pendampigan secara berkelanjutan. Diperlukan kegiatan tindak lanjut yang berfokus pada pemberdayaan orang tua (parenting), sedangkan harapan peserta untuk kegiatan selanjutnya yang di berikan oleh peserta untuk meningkatkan ketrampilan guru khususnya dalam mendampingi siswa dalam meningkatkan soft skill siswa meliputi cara mengidentifikasi karakter \& kepribadian siswa, pelatihan menjadi guru yang smart, ketrampilan memotivasi siswa.

\section{DAFTAR PUSTAKA}

Alcántara, S. C., González-Carrasco, M., Montserrat, C., Viñas, F., Casas, F., \& Abreu, D. P. (2016). Peer violence in the School Environment and Its Relationship with Subjective Well-Being and Perceived Social Support. 

$-1$

Estévez, E., Jiménez, T.I., \& Cava, María Jesús (2016). A cross-cultural study in Spain and Mexico on school aggression in adolescence: Examining the role of individual, family and school variables. Cross-Cultural Research, 20,1-31.

Habibi , M. (2015). Analisis kebutuhan anak usia dini . Buku Ajar S1 PAUD, Yogyakarta : Deepublish

Herrero Juan, Estefania \& Gonzalo.(2006). The Relationships Of Adolescent School-Related Deviant Behaviour And Victimization With Psychological Distress; Testing A General Mode Of Tehe Mediational Role Of Parents And Teachers Across Groups Of Gender And Age. Journal Of Adolesence, 671-690

Hidayat, H., Yusri, \& Ilyas, A. (2013). Profil Siswa Agresif dan Peranan Guru BK. Jurnal Ilmiah Konseling, 2(1), 1-5.

Little, T.D., Henrich, C.C., Jones, S.M., \& Hawley, P.H. (2003). Disentangling the "whys" from the "whats" of aggressive behaviour. International Journal of Behavioral Development, 27, 122-131.

Martínez, B., Murgui, S., Musitu, G., \& Monreal, M.C. (2009). El rol del apoyo parental, las actitudes hacia la escuela y la autoestima en la violencia escolar en adolescentes [The role of parental support, attitudes towards school and self-esteem in school violence in adolescents]. International Journal of Clinical and Health Psychology, 8, 679-692

Martínez, B., Povedano, A., Amador, L.V., \& Moreno, D. (2012). Clima escolar, satisfacción con la vida y victimización en la escuela. Un análisis del efecto moderador del género [School climate, satisfaction with life and victimization in school. An analysis of the moderating effect of gender]. Anales de Psicología, 28, 875-882.

Taftazani. 2013. Deteksi Dan Intervensi Dini Pada Kenakalan Remaja. Bandung: Universitas Pajajaran.

Vanderbilt, D., \& Augustyn, M. (2010). The Effects of Bullying. Pediatric and Child Health, Sympossium Special Needs Elsevier Ltd., 20:7.

Villarreal-González, M. E., Sánchez-Sosa, J. C., Veiga, F. H., \& del Moral Arroyo,G.(2011).Developmentcontexts,psychologicaldistress, socialselfesteem and school violence from a gender perspective in Mexican adolescents. Psychosocial Intervention, 20,171-181. 